\title{
30 YEARS OF THE MINERALOCORTICOID RECEPTOR Mineralocorticoid receptor null mice: informing cell-type-specific roles
}

\author{
Timothy J Cole ${ }^{1,2}$ and Morag J Young ${ }^{2,3}$ \\ 1Department of Biochemistry and Molecular Biology, Monash University, Melbourne, Victoria, Australia \\ ${ }^{2}$ Centre for Endocrinology and Metabolism, Hudson Institute of Medical Research, Monash Medical \\ Centre, Clayton, Victoria, Australia, and ${ }^{3}$ Department of Molecular and Translational Research, Monash \\ University, Melbourne, Victoria, Australia
}

Correspondence should be addressed to $\mathrm{T}$ J Cole

Email

tim.cole@monash.edu

\begin{abstract}
The mineralocorticoid receptor (MR) mediates the actions of two important adrenal corticosteroid hormones, aldosterone and cortisol. The cell signalling roles of the MR in vivo have expanded enormously since the cloning of human MR gene 30 years ago and the first MR gene knockout in mice nearly 20 years ago. Complete ablation of the MR revealed important roles postnatally for regulation of kidney epithelial functions, with MR-null mice dying 1-2 weeks postnatally from renal salt wasting and hyperkalaemia, with elevated plasma renin and aldosterone. Generation of tissue-selective MR-deficient mice using Cre recombinase-LoxP gene targeting has made it possible to analyse mice lacking MR only in specific cell types. Targeting renal-specific MR has differentiated roles in specific compartments of the kidney. Ablating MR in neurons of the forebrain reinforced important roles of the MR in response to stress, behaviour and anxiety, but suggested a minimal role in maintaining basal HPA axis tone. Deletion of the MR in macrophages and other cell types of the cardiovascular system clearly defined important roles for the regulation of cardiovascular physiology and pathophysiology. Knockdown of MR mRNA in vivo using antisense/siRNA approaches, and similarly MR overexpression, has provided useful rodent models to study physiological roles of MR signalling in vivo. More recently, targeted mutation of specific domains of the MR such as the DBD has defined genomic vs non-genomic roles in vivo. New tissue-selective MR-null models are required to define roles of MR signalling in other regions of the brain, the eye, gastrointestinal tract, lung, skin, breast and gonadal organs.
\end{abstract}

Key Words
- aldosterone
- cortisol
- mineralocorticoid
receptors
- null mice

Journal of Endocrinology (2017) 234, T83-T92

\section{Introduction}

The mineralocorticoid receptor (MR) is an intracellular steroid hormone receptor, and a member of the nuclear receptor superfamily, that mediates the physiological action of two important adrenal steroids, aldosterone and cortisol (Funder 2010, Gomez-Sanchez \& Gomez-Sanchez 2014). Both steroids have important homeostatic roles in the body, and the absence or excess of these steroids causes significant Printed in Great Britain clinical disease such as Cushing's syndrome with excess cortisol and hyperaldosteronism with elevated aldosterone (Funder 2017). These conditions can now be treated with a range of effective and specific GR or MR antagonists (Yang \& Young 2016). In the kidney and colon, aldosterone acts via the MR to stimulate sodium reabsorption and potassium loss to regulate electrolyte homeostasis. The MR is also

This paper is part of a thematic review section on 30 Years of the Mineralocorticoid Receptor. The guest editors for this section were John Funder and Maria,Ghristina ZennarQioscientifica.com at 04/26/2023 01:49:03PM 
expressed in a wide range of non-epithelial cells including areas of the brain, adipose tissue, the heart and vessel wall. Receptor selectivity for aldosterone is not always the case in these cells allowing cortisol to regulate transcriptional responses via a nuclear receptor in addition to GR. Moreover, cortisol can have both agonist and antagonist actions at the MR depending on cell context and whether enzymatic 'protection' of the MR is present.

The diversity of cell signalling roles via the MR has expanded enormously since the cloning of the human MR and first mouse gene knockout of the MR nearly 20 years ago, to be discussed in detail in this review (Arriza et al. 1987, Berger et al. 1998). Development of specialised, genetically modified animal models that interrogate the physiological role of the MR in specific cell or tissue compartments has facilitated numerous studies that have defined and dissected novel cell-type-specific actions of the MR in vivo. This review will describe the insights on the role of the MR and its signalling pathways across a range of tissues and cells gained from analysis of cell-type selective knockouts, modulation and mutation of the MR gene in the mouse (summarised for specific mouse models below in Table 1), that began almost 20 years ago in a small university town in Germany (Berger et al. 1998).

\section{The adrenal corticosteroids, MR signalling in cells and MR antagonists}

The cells of the adrenal cortex synthesise the corticosteroids aldosterone, cortisol and corticosterone (rats, mice) and in humans, the adrenal androgens androstenedione, dehydroepiandrostenedione sulphate and $11 \beta$-hydroxyandrostenedione via a well-characterised steroid biosynthetic enzyme pathway (Baker 2004). Aldosterone synthesis in the adrenal is primarily regulated by increasing the activity of the key biosynthetic enzyme aldosterone synthase (CYP11B2), normally in response to angiotensin II (AngII) or elevated plasma $\left(\mathrm{K}^{+}\right)$. The adrenal steroids act via binding to and activating either the $\mathrm{MR}$, glucocorticoid receptor (GR) or androgen receptor (AR), which are all members of the steroid hormone subfamily of nuclear receptors (McKenna et al. 2014). The MR in target cells can be activated by aldosterone and glucocorticoids with almost identical binding affinities; unprotected MRs thus act primarily as a high-affinity GR due to the much higher circulating and intracellular concentrations of glucocorticoids. In aldosterone target cells and tissues, specificity is afforded by the expression of the 11 1 -hydroxysteroid dehydrogenase type II $(11 \beta-H S D 2)$ enzyme that efficiently metabolises

Table 1 Phenotypes of tissue or cell-type-specific MR-null mice.

\begin{tabular}{|c|c|c|c|}
\hline Tissue compartment & Cre driver & Phenotype & Cell-specific effects \\
\hline Complete null & None (all cells) & $\begin{array}{l}\text { Early postnatal death from } \\
\text { sodium and fluid loss }\end{array}$ & $\begin{array}{l}\text { Elevated renin, high } \\
\text { aldosterone ENaC and } \\
\mathrm{Na} / \mathrm{K}-\mathrm{ATP} \text { - }\end{array}$ \\
\hline Renal tubule & Aqp2-Cre (CD and CNT) & $\begin{array}{l}\text { Survival to adult, elevated } \\
\text { RAAS activity }\end{array}$ & $\begin{array}{l}\mathrm{Na}+/ \text { water loss on a low } \\
\text { Na-diet }\end{array}$ \\
\hline Renal nephron & Pax8-Cre (Nephron) & $\begin{array}{l}\text { Survive with severe PHA-1, } \\
\text { die on } \mathrm{Na}^{+} \text {-deficient diet }\end{array}$ & $\begin{array}{l}\text { Reduced renal ENaC } \alpha \& \\
\mathrm{Na}^{+} / \mathrm{Cl}-\text { co-transporter } \\
\text { levels }\end{array}$ \\
\hline Forebrain/CNS & CamKII-Cre (Neurones) & $\begin{array}{l}\text { Impaired learning and } \\
\text { memory, altered level of } \\
\text { anxiety }\end{array}$ & $\begin{array}{l}\text { Neural mossy-fibre } \\
\text { abnormalities, increased } \\
\text { GR levels in the brain }\end{array}$ \\
\hline VSMC & $\begin{array}{l}\text { SMA-CRE/ERT2 } \\
\text { (smooth muscle) }\end{array}$ & $\begin{array}{l}\text { BP regulation in ageing, } \\
\text { altered vascular tone }\end{array}$ & $\begin{array}{l}\text { Induced VSM } \alpha 5 \text {-integrin, } \\
\text { Aldo/salt }\end{array}$ \\
\hline \multirow[t]{2}{*}{ Endothelial cell } & Tie2-Cre & \multicolumn{2}{|c|}{$\begin{array}{l}\text { No DOC/salt cardiac fibrosis, no macrophage } \\
\text { recruitment }\end{array}$} \\
\hline & VE-Cad-Cre & \multicolumn{2}{|c|}{ Obesity-induced dysfunction blunted inflammation } \\
\hline \multirow[t]{2}{*}{ Cardiomyocyte } & MLC2a-Cre & \multicolumn{2}{|c|}{ Improved cardiac remodelling (post-infarct) } \\
\hline & MLC2v-Cre & \multicolumn{2}{|c|}{ Protected from DOC/salt cardiac fibrosis } \\
\hline \multirow[t]{4}{*}{ Myeloid/macrophage } & LysM-Cre & \multicolumn{2}{|c|}{$\begin{array}{l}\text { Protected from DOC/salt fibrosis and hypertension, } \\
\text { protected }\end{array}$} \\
\hline & & \multicolumn{2}{|c|}{$\begin{array}{l}\text { Protected from L-NAME/salt fibrosis but not } \\
\text { hypertension }\end{array}$} \\
\hline & & \multicolumn{2}{|c|}{$\begin{array}{l}\text { Reduced macrophage recruitment in stroke and } \\
\text { Angll/L-NAME }\end{array}$} \\
\hline & & \multicolumn{2}{|c|}{$\begin{array}{l}\text { Fibrosis, but not hypertension; protection from } \\
\text { atherosclerosis }\end{array}$} \\
\hline
\end{tabular}

Reference

Berger et al. (1998)

Ronzaud et al. (2007)

Canonica et al. (2016),

Terker et al. (2016)

Berger et al. (2006)

McCurley et al. (2012)

Rickard et al. (2014)

Schafer et al. (2013) Jia et al. (2015)

Fraccarollo et al. (2011)

Rickard et al. (2012)

Rickard et al. (2009)

Bienvenu et al. (2012)

Usher et al. (2010)

Frieler et al. (2011), Shen et al. (2016) 
intracellular cortisol or corticosterone to inactive steroids. The MR, in contrast to the GR, which is ubiquitously expressed, has a restricted expression pattern in mammals, and is expressed in the epithelia of organs such as the kidney, colon and salivary gland, where it primarily acts as the receptor for aldosterone to regulate fluid and electrolyte/solute homeostasis. Interestingly during the neonatal period of a few weeks, renal MR expression is very low causing an apparent renal resistance to aldosterone with characteristic neonatal salt wasting (Martinerie et al. 2009, 2011). The MR is also found in non-epithelial tissues including the heart, hippocampal and hypothalamic neurons, adipocytes, keratinocytes, endothelial cells, vascular smooth muscle cells (VSMC), and in a number of cell types of the immune system. In many of these compartments/tissue types, the MR is unprotected by $11 \beta$-HSD 2 and is thus predominantly occupied and in some circumstances activated by cortisol.

The classic mechanism of signalling for the activated MR is similar to other steroid hormone receptors. Ligandbound and activated MRs translocate to the nucleus and bind as a dimer via a zinc finger DNA-binding domain to specific hormone response elements (HREs) in genomic DNA, recruiting a complex group of transcriptional coactivators to regulate a specific subset of target genes. Although many coactivators have been described that interact with most steroid hormone receptors, such as the SRC1-3 family, a few MR-specific coactivators have been identified such as FAF-1 and recently tesmin (Obradovic et al. 2004, Rogerson et al. 2014). These studies reveal the ligand-specific actions of the MR that determine receptor selectivity and tissue-specific actions to be reviewed in detail in this Anniversary Issue.

Important synthetic MR antagonists (MRAs), such as spironolactone, finerenone and eplerenone, have been developed and are currently utilised to treat ascites and more recently in the management of heart failure (Zannad et al. 2011). Despite the clear benefits of MRAs for the treatment of heart failure, a better understanding of the underlying mechanisms that account for these beneficial effects is still lacking. Of note, the non-steroidal MRA finerenone has recently been shown to prevent full nuclear import of MR, and inhibit MR and coactivator binding to genomic target genes (Amazit et al. 2015). Moreover, concerns about elevated potassium resorption with the use of current MRAs remain a key reason for their limited use in the clinic. Therefore, to further understand the role of the MR in vivo and to delineate MR-regulated functions in specific cell types or compartments, genetic studies in animal model systems are required. The analysis of MR loss-of-function alleles in vivo in mice has provided enormous insight into the functional importance and the roles of MR signalling in specific epithelial and nonepithelial tissues and compartments.

\section{Complete ablation of the mouse MR gene in mice}

The first MR-deficient or null mouse model was developed almost 20 years ago by Schutz and coworkers using the technology of gene-targeting in embryonic stem cells (Berger et al. 1998). Mice lacking the MR developed relatively normally to birth but during the first week postnatally developed symptoms of pseudohypoaldosteronism, losing weight with a failure to survive and eventually died by day 10. MR-null mice displayed hyperkalaemia, hyponatraemia and highly elevated renin, angiotensin II and aldosterone. Additional analysis of the reninangiotensin-aldosterone system (RAAS) in 8-day-old MR-null mice showed highly elevated renin expression in the kidney with increased recruitment of renin-producing cells. In the liver, angiotensinogen and AT1 receptor mRNA levels were moderately elevated (Hubert et al. 1999). Interestingly, heterozygous MR mice showed no alterations in any of the RAAS components tested. These studies clearly demonstrated a critical requirement for MR signalling in the kidney and presumably the colon in the early postnatal period.

To enable the study of total MR-deficient mice into adulthood, rescue of the urinary sodium and water loss was attempted with twice-daily injections of sodium chloride $(3.85 \mu \mathrm{mol} / \mathrm{g}$ BW) until a body weight of $8.5 \mathrm{~g}$, whereby mice were given saline to drink (Bleich et al. 1999). This was sufficient to rescue most MR-deficient mice up to an age of approximately 7 weeks. However, there was a pronounced delay in the growth of MR-deficient mice until approximately day 20 , the renal renin-producing cells were hypertrophic and hyperplastic, and plasma renin and aldosterone levels were highly elevated indicating the persistence of a renal salt losing defect (Bleich et al. 1999). The difficulty of maintaining these mice and their complicated systemic defects made them unsuitable for studies on the role of the MR in other tissue compartments or cell types. Development of the Cre recombinase-LoxP gene targeting technology at approximately the same time was thus used to ablate gene expression selectively in cells or tissue to allow the generation of tissue-selective MR-deficient mice (Wintermantel et al. 2005).
Published by Bioscientifica Ltd 
Three research groups have now created so-called 'MR-floxed' mice where 34 base-pair LoxP-Cre recombinase binding sites have been positioned in the mouse genome by homologous recombination to flank critical, but different, exons in the MR gene. By crossing MR-floxed mice with tissue-specific Cre recombinase transgenic mice, targeted ablation of MR gene expression in specific cell types was achieved (Berger et al. 2006, Rickard et al. 2009, McCurley et al. 2012). Two research groups used mice harbouring LoxP flanked exon 3 of the MR gene that encodes the first zinc finger of the MR DNA-binding domain (DBD) (Berger et al. 2006, Rickard et al. 2009) while the third flanked exons 5 and 6 encode the hinge region and N-terminal part of the ligand-binding domain (LBD) (McCurley et al. 2012). In each case, deletion of these exons introduced a frameshift to the coding region of the gene and introduction soon after of a premature stop codon. The following sections will describe the phenotypes and insights gained of new functional roles of the MR from a growing number of studies analysing tissue-selective MR-deficient or MR-null mice.

\section{Epithelial cell-specific deletion of the MR gene}

The role of renal MR in collecting duct principal cells was further investigated by Schutz and coworkers by crossing MR-floxed mice with a Cre recombinase transgenic mouse where Cre was driven by the Aquaporin-2 gene promoter (Ronzaud et al. 2007). Loss of MR was restricted to collecting ducts and late connecting tubules, and under a standard diet $\mathrm{MR}^{\mathrm{AQP} 2 \mathrm{Cre}}$ mutant mice survived postnatally and developed normally to adulthood, although they had elevated plasma aldosterone levels. When challenged with a low sodium diet, however, the mice had increased sodium and water excretion and loss of body weight. Two more recent independent studies have deleted the MR along the mouse adult nephron via a tamoxifeninducible Pax 8-Cre recombinase transgene from four weeks (Canonica et al. 2016) and eight weeks (Terker et al. 2016) of age. In contrast to the MR ${ }^{A Q P 2 C r e}$ mutant mice, adult MRPax 8-Cre mice in both studies showed features of severe PHA-1 on a normal sodium diet, significant weight loss, high urinary sodium excretion, hyperkalaemia and elevated plasma aldosterone. On a sodium-deficient diet, nephron-specific MR-deficient mice in both studies rapidly worsen with a more severe phenotype despite key MR targets and electrolyte regulators $\mathrm{ENaC} \alpha$ and the $\mathrm{Na}^{+} / \mathrm{Cl}^{-}$ co-transporter being downregulated in MR nephron mutant mice. In summary, loss of nephron MR closely mirrored a severe form of human PHA-1.

No studies to date have reported MR deletion in colonic epithelium but this could be achieved with a number of gastrointestinal tract epithelium-specific Cre mice (el Marjou et al. 2004). Deletion of the MR in a third epithelial compartment, the skin, was recently reported using a Keratin5-Cre recombinase transgenic mouse crossed with the exon $3 \mathrm{MR}$-floxed mouse to delete the MR in epidermal keratinocytes (Boix et al. 2016). MR epidermal null mice displayed higher keratinocyte cell proliferation and differentiation, and were resistant to glucocorticoidinduced thinning of the epidermis. There was however increased sensitivity to inflammatory skin damage, and mice showed elevated cytokine induction. These results demonstrated an important role for MR-mediated signalling in the skin to maintain homeostasis and cooperate with GR to mediate glucocorticoid responses.

\section{Ablation of the MR in specific cellular compartments of the cardiovascular system}

Human clinical trials, such as RALES and EPHESUS have demonstrated benefits of MR antagonism with the treatment of patients with heart failure (Pitt et al. 1999, 2001). This led to renewed interest on the role of MR signalling in cardiovascular physiology and function, with a number of groups targeting the MR for ablation in vascular smooth muscle (VSMC), cardiomyocytes, endothelial cells and macrophages using specific transgenic Cre recombinase approaches. Deletion of the MR in VSMC compartments of adult mice was achieved by Jaffe and coworkers using a tamoxifen-inducible SMACre-ER ${ }^{\mathrm{T} 2}$ transgenic mouse to delete exons 5 and 6 of the MR gene in vascular smooth muscle (McCurley et al. 2012). These mice developed decreased blood pressure without renal sodium defects or abnormalities in vascular structure. Aged VSMC-MR-deficient mice had reduced myogenic tone and other minor vascular abnormalities. Subsequent studies showed vascular remodelling defects and deficits in vascular tone but no change in the vascular response in vitro to other acute pressor agents such as AngII (Pruthi et al. 2014, Amador et al. 2016).

Deletion of the MR in endothelial cells (EC) was achieved by three groups using different Cre recombinase approaches, one with Tie2-Cre recombinase and the others a VE-cadherin Cre recombinase (Schafer et al. 2013, Rickard et al. 2014, Mueller et al. 2015). In the first study using VE-cadherin-Cre, Schafer and coworkers

Published by Bioscientifica Ltd 
showed that endothelial cell MR are required for obesity-induced vascular dysfunction by regulating the production of oxidative stress and vascular inflammation which in turn promotes vascular dysfunction. Rickard and coworkers also investigated vascular functional responses in vitro using Tie-Cre to generate EC-MRKO mice (Rickard et al. 2014). In these animals, aortic rings from unchallenged mice displayed deficits in vascular nitric oxide response compared to WT large arteries suggesting dysfunction of the nitric oxide relaxation pathway. In a deoxycorticosterone (DOC)/salt model of cardiovascular disease from the same group, EC-MRKO mice were protected from macrophage infiltration and pro-inflammatory responses in the myocardium with no change in blood pressure responses (Rickard et al. 2014). Mueller and coworkers also investigated blood pressure control in VE-cadherin Cre EC-MRKO mice with telemetric analysis and again showed no difference in normal blood pressure parameters. However, responses to angiotensin II, endothelin-1 and thromboxane in vitro were impaired indicating a modulatory, rather than a central, role for EC-MR in pathological states such as hypertension (Mueller et al. 2015). Vascular and cardiac responses were similarly assessed following 16 weeks of a high-fat diet by another group who demonstrated that EC-MR play a key role in the activation of cardiac inflammatory and profibrotic responses leading to cardiac diastolic dysfunction and aortic stiffness in female mice (Jia et al. 2015, 2016).

The role of cardiomyocyte MR was also examined in cardiac remodelling by deletion of the MR with a cardiac-specific myosin light chain $2 \alpha-C r e ~(M L C 2 \alpha$; (Fraccarollo et al. 2011)) and the myosin light chain2v-Cre (MLC2v) (Rickard et al. 2012). Fraccarollo and coworkers investigated the role of the cardiomyocyte MR in the short and long term cardiac functional response to coronary artery ligation. While loss of MR signalling in cardiomyocytes had no effect on baseline cardiac function, knockout animals subjected to experimental infarct had improved scar generation in the necrotic region, increased capillary density and less oxidative stress/inflammation. At later time points, cardiac function was significantly improved and the non-infarcted tissue showed less remodelling overall demonstrating a clear role for MR signalling in the detrimental remodelling in the post-infarct heart. In contrast, Lother and coworkers, using the same Cre recombinase and approach to generate MR null mice, investigated a model of pressure overload (TAC) and found that loss of cardiomyocyte MR did not change the tissue hypertrophy or fibrotic response, but left ventricular function was significantly improved (Lother et al. 2011).

These data support previous demonstrations that the various pathological roles of the MR do not always present together and further reveal that the specific role of the MR in pathology is cell contextdependent. Investigation of cardiomyocyte tissue fibrosis and inflammation in the reactive fibrosis model of deoxycorticosterone/salt treatment over 8 weeks showed MR-null mice to be once again protected (Rickard et al. 2012). Inflammatory cell infiltration, collagen deposition and pro-inflammatory marker responses were all blocked in these mice, while some anti-fibrotic factors (e.g. decorin) were upregulated suggesting a direct role for cardiomyocyte MR in the development of cardiac fibrosis. Further study in an ischaemia-reperfusion injury model showed that cardiomyocyte MR null also contributed to electromechanical responses to cardiac hypertrophy and damage at least in part due to changes in NHE-1 levels and phosphorylation of Calcium/calmodulin kinase 2 (CamKs) (Bienvenu et al. 2015).

Finally the role of MR signalling in myeloid monocyte/macrophage responses in cardiovascular function and disease were assessed by two groups that generated macrophage MR-null mice with the Lysozyme M-Cre recombinase (Rickard et al. 2009, Frieler et al. 2011). Deletion of MR from macrophages afforded complete protection from cardiac fibrosis and hypertension in a deoxycorticosterone/salt model of cardiovascular disease (Rickard et al. 2009), in acute treatment of L-NAME/ AngII-mediated cardiac fibrosis (Usher et al. 2010) and in chronic L-NAME/salt treated mice, a model of chronic nitric oxide depletion (Bienvenu et al. 2012). A number of differences were noted in the various studies, despite the overall cardioprotective effects that most likely reflect the particular model used. Rickard and Bienvenu found no change in the recruitment of monocytes and macrophages to the heart, but a change in the expression of inflammatory and profibrotic markers including PAI-1, TGF $\beta$ and iNOS. Usher on the other hand reported a significant reduction in tissue macrophages, an effect also seen in two studies investigating macrophage MR null mice subjected to experimental stroke (Frieler et al. 2012).

Taken together, these studies show that MR signalling in the myeloid cell population is required for the proinflammatory phenotype, and that loss of MR promotes an alternative macrophage phenotype that has some common markers with certain 'M2' macrophage subsets. In an effort to determine the cellular mechanisms of 
MR signalling in monocytes/macrophages Usher and coworkers performed microarray on peritoneal-derived macrophages and showed MR null cells to have a gene expression pattern that overlapped with GR and PPAR $\gamma$ agonist activity. Shen and coworkers (2016) isolated cardiac tissue macrophages from vehicle and DOC/ salt treated mice and found that pro-inflammatory and pro-fibrotic profiles were indeed lost but the alternative activation profile was not pronounced (Shen et al. 2016). Another group identified JNK signalling pathways to be MR dependent and potentially NFkB signalling (Shen et al. 2016, Sun et al. 2016). Thus in less than a decade, there has been significant steps towards dissecting and defining the cellular mechanisms of MR signalling in the cardiovascular system. These studies underscore observations from earlier studies showing that direct effects of MR signalling in the heart were responsible for cardiac disease progression, rather than secondary hemodynamic effects of MR activation in the nephron (Young \& Funder 1996).

\section{Gene-targeted ablation of the MR in regions of the brain}

The MR, unlike the ubiquitous GR, is expressed only in neurons and particularly in the limbic system, where MR are most abundantly expressed in the hippocampus; they are also found in the lateral and medial septum and regions of the amygdala (Kolber et al. 2008). Absence of $11 \beta$-HSD2 in these regions means the MR are primarily glucocorticoid activated and co-localisation of GR and MR in neurons implies a complex signalling regulation of neural target genes by glucocorticoids in particular, and in the presence of $11 \beta$-HSD 2 potentially by aldosterone as well (de Kloet et al. 2005). Analysis of the brain in saltrescued, complete MR adult null mice showed decreased granule cell density in the hippocampus and a market reduction in granule cell neurogenesis (Gass et al. 2000). This was in contrast to brain-specific GR-null mice where neurogenesis in this region was unaltered. To further dissect specific neural roles for MR in the brain Schutz and coworkers deleted MR expression in the forebrain of the mouse with a CaM-Kinase (CamKII) Cre recombinase driven approach in MR-floxed mice (Karst et al. 2005, Berger et al. 2006). Learning and behaviour tests of mutant mice showed impaired learning, deficits in working memory and some alterations in measures of anxiety. These changes were associated with mossy-fibre histological abnormalities and increased expression of the GR. Rapid responses to corticosterone in a well characterised non-genomic pathway in hippocampal CA1 neurons were then assessed in brain hippocampal slices for both brain-specific GR- and MR-null mice. In contrast to the GR, MR were required for normal steroid agonist and antagonist excitatory postsynaptic responses (Karst et al. 2005), consistent with MR involvement in both genomic and non-genomic steroid actions in the brain.

To further address the role of the MR in corticosteroid modulation in the brain of stress related disorders, mice deficient for MR in forebrain (described above) were tested for the effect of stress on emotional and cognitive behaviours (Brinks et al. 2009). MR forebraindeficient mice had higher arousal and less exploratory activity following $5 \mathrm{~min}$ of restraint stress, and in a fear conditioning test showed greater cue-related freezing. There were also subtle defects in memory and $40 \%$ higher levels of plasma corticosterone. Absence of forebrain MR augmented anxiety related responses and clearly shows the importance of corticosteroid hormone and receptor balance for responses to stress. Two research groups have generated transgenic mice overexpressing the MR in the forebrain via the CamKII promoter, both increasing MR levels by $25-40 \%$ (Lai et al. 2007, Rozeboom et al. 2007). Both MR overexpression models showed no change in the basal tone of the HPA axis but both had reduced anxietylike behaviour in open field tests. This was suggested to be partially due to increased expression of serotonin receptors in one of these transgenic lines (Rozeboom et al. 2007). Brain MR-overexpressing mice also displayed enhanced spatial memory in the Morris water maze test and alterations in their ability to recognise novel objects. These studies questioned the role of MR in basal HPA axis drive but further defined its role in the stress response, anxiety and depressive behaviours.

\section{Knockdown of MR levels in vivo by antisense mRNA or RNAi approaches}

Analysis of MR signalling has also been assessed in transgenic rodent models in vivo using a range of mRNA knockdown approaches. Jassier and coworkers created an inducible and cardiac-specific transgenic mouse that expressed in antisense MR mRNA with the cardiac $\alpha$ myosin heavy chain promoter under a doxycycline-dependent tTA transactivator (Beggah et al. 2002). Within 2-3 months of MR mRNA knockdown mice developed cardiac fibrosis and severe heart failure, without development of hypertension or elevated serum aldosterone. This phenotype was

Published by Bioscientifica Ltd. 
reversible upon removal of doxycycline and cessation of antisense mRNA production. However, while these data suggest a specific contribution of MR signalling to the maintenance of normal cardiac physiology, and that its absence leads to development of heart failure and cardiac fibrosis, the more recent cell-specific MR deletion studies do not show a similar phenotype. MR knockdown approaches have also been attempted using shRNA and siRNA treatments. Sun and coworkers injected MRshRNA expressing adeno-associated viral particles to the tail vein of adult mice and then assessed responses to cold-induced hypertension (Sun et al. 2008). Mice were injected $48 \mathrm{~h}$ before cold exposure and blood pressure measured weekly for 4-5 weeks. Injection of MRshRNA AVV particles blocked normal cold-induced elevation of blood pressure, with no change in body weight, but increased food intake, water intake and urinary output. There was evidence of blunted RAAS responses but analysis of MR levels in the kidney, heart and hypothalamic regions showed there was only a moderate reduction in MR expression. The exact mechanism of MRshRNA-mediated blockade of coldinduced hypertension is thus as yet unclear.

Silencing MR in vivo using RNAi has also been attempted in a transgenic rat model using a lentiviral-MRspecific shRNA injected into fertilised oocytes (Lim et al. 2008). Resulting transgenic rats at 3 weeks of age showed reduced expression of MR mRNA in the kidney cortex and hippocampus to levels between 5 and 40\%. Similar to complete MR-null mice MRshRNA rats had reduced body weight, elevated plasma aldosterone, increased renin activity and altered expression of renal MR target genes. Most transgenic rats survived to adulthood providing a rodent model of pseudo-hyperaldosteronism that could be assessed in future studies. A more elegant RNAi-based MR knockdown transgenic model has been recently created by the same group using a doxycycline induced MRshRNA approach in mice (Montes-Cobos et al. 2015). This transgenic model used the Tet-repressor to block expression of an MRshRNA transgene that would only become active when adult mice were treated with doxycycline. Two weeks following treatment MR expression was reduced by up to $80 \%$ of normal levels in some tissues with a similar reduction in the expression of a number of direct MR target genes. There was also a marked elevation in plasma aldosterone and renin levels, and increased urinary sodium excretion. In the heart, collagen expression and deposition was also normal, and no change in blood pressure was reported. To examine the effect of modest MR reduction to cardiac overload MRshRNA transgenic mice were surgically treated with
TAC. Four weeks after surgery there was a significant attenuation to the induced cardiac hypertrophy and progression to heart failure. This inducible transgenic MR knockdown mouse model will thus be very useful to examine a range of cardiovascular, renal and neurological roles for MR-mediated signalling in vivo. Finally, siRNAmediated knockdown of MR has been performed in cultured mouse preadipocytes and is compared to similar knockdown of the GR and a similar analysis in MR and GR knockout or null adipocyte cell lines derived from total GR- or MR-null embryos (Hoppmann et al. 2010). Aldosterone-stimulated in vitro cultured white adipocytes induced expression of pro-inflammatory markers such as IL6 and PAI-1, suggesting that MR-mediated signalling in adipocytes was pro-inflammatory. MR-null adipocytes however failed to accumulate lipids.

\section{Targeted mutation to domains of the MR gene in vivo}

To dissect the role of specific domains of steroid hormone receptors, targeted subtle mutations have been undertaken for the GR and MR genes. To separate genomic (via DNA binding) vs non-genomic signalling by the GR and MR in vivo, the DNA-binding domain of both receptor genes have been mutated in vivo in mice by gene-targeting approaches. In the first study on the GR, exon 4 encoding the 2nd zinc finger of the GR DNAbinding domain important for receptor or dimerisation was mutated by a single A458T mutation (Reichardt et al. 1998). The resulting so-called 'GR-Dim' mice were born normally and survived from birth unlike complete GR-null mice (Cole et al. 1995). Transrepression functions of the GR remained intact, with a mild activation of the HPA axis and a loss of glucocorticoid-induced apoptosis in thymocytes. This also indicated that GR dimerisation and potentially DNA binding was not required for perinatal-specific glucocorticoid signalling, particularly in the respiratory system which is compromised in GR-null mice. An open question still remains, of whether this GR dimerisation mutant mouse is capable of GR-specific binding to genomic DNA via classic GREs, and therefore regulating some target gene transcription in vivo. Recently, a similar 'MR-Dim' mouse has been generated by gene targeting where a single amino acid substitution of C603S has been made in exon 3 of the mouse MR gene (Cole et al. 2015). Homozygous MR-Dim mice are born but failed to thrive 4-5 days after birth, progressively lose weight and die between days 10 and 13 postnatally, which is almost

Published by Bioscientifica Ltd 
identical to the phenotype of complete MR-null mice. Homozygous MR-Dim mice can be rescued by twicedaily saline injections but are smaller than controls with a reduced rate of growth. Similar to MR-null mice, there is elevated plasma aldosterone and plasma renin activity. These studies indicate that intact MR DNA binding is required for normal aldosterone-mediated renal solute and water transport shortly after birth. There are currently no published studies in mice where potentially important residues within the LBD of the MR have been tested by mutation in vivo. However, a curious single amino acid mutation in the human MR gene does shed some light on the determinants of steroid binding. An activating human MR mutation S810L in the LBD causes early onset hypertension which dramatically increases during pregnancy (Geller et al. 2000). This mutation caused a constitutively active MR, potentially activated by cortisol and further stimulated by progesterone, normally a competitive MR antagonist, now acting during pregnancy as an agonist of the MR (Rafestin-Oblin et al. 2003).

\section{Summary and future perspectives}

Over the past nearly 20 years, the cell-type-specific ablation of the MR gene in mice for a range of tissues and cell types has delivered important information on the specific roles of MR-mediated cell signalling in normal physiology and in the pathology of disease. Of particular focus has been separating epithelial vs non-epithelial roles, particularly in the kidney and specific cell types of the cardiovascular system. Other tissue components yet to be interrogated by MR ablation in a mouse model include the eye, segments of the gastrointestinal tract, lung, skin, breast epithelium and the gonadal organs. This should provide a more detailed information for the assessment of whole-body effects for the next generation of MR agonist and antagonists, particularly those that separate renal vs cardiac effects. Future transgenic studies require better more tightly regulated Cre recombinase driver transgenic mice that allow temporal induction by simple drugs such as tamoxifen or doxycycline at different phases of the life-cycle. Current worldwide transgenic networks such as EUCOMM will soon provide a catalogue of Cre recombinase driver transgenic mice specific for most cell types and compartments of the mammalian body, which can then be used to delete the MR gene when and where required (Friedel et al. 2011). In the future, the CRISPR/ cas9 gene-editing system also promises to provide lowcost and efficient generation of mice with subtle MR gene mutations to delineate MR domain-specific roles and interactions, and to interrogate specific interactions with nuclear coactivator and co-repressors in vivo (Ran et al. 2013). These approaches will improve our understanding of complex unanswered questions such as determinants of ligand specificity, the role of GR/MR heterodimer interactions in vivo and the selective recruitment of coactivator or corepressor complexes by different steroid and non-steroidal ligands.

\section{Declaration of interest}

The authors declare that there is no conflict of interest that could be perceived as prejudicing the impartiality of this review.

\section{Funding}

This work was supported by funding from the National Health and Medical Research Council of Australia (Program 384100). The Hudson Institute is supported by the Victorian Government's Operational Infrastructure Support Program.

\section{Acknowledgements}

The authors are grateful to Judy $\mathrm{Ng}$ for help with the preparation of this manuscript.

\section{References}

Amador CA, Bertocchio JP, Andre-Gregoire G, Placier S, Duong Van Huyen JP, El Moghrabi S, Berger S, Warnock DG, Chatziantoniou C, Jaffe IZ, et al. 2016 Deletion of mineralocorticoid receptors in smooth muscle cells blunts renal vascular resistance following acute cyclosporine administration. Kidney International 89 354-362. (doi:10.1038/ki.2015.312)

Amazit L, Le Billan F, Kolkhof P, Lamribet K, Viengchareun S, Fay MR, Khan JA, Hillisch A, Lombes M, Rafestin-Oblin ME, et al. 2015 Finerenone impedes aldosterone-dependent nuclear import of the mineralocorticoid receptor and prevents genomic recruitment of steroid receptor coactivator-1. Journal of Biological Chemistry 290 21876-21889. (doi:10.1074/jbc.M115.657957)

Arriza JL, Weinberger C, Cerelli G, Glaser TM, Handelin BL, Housman DE \& Evans RM 1987 Cloning of human mineralocorticoid receptor complementary DNA: structural and functional kinship with the glucocorticoid receptor. Science 237 268-275. (doi:10.1126/ science.3037703)

Baker ME 2004 Co-evolution of steroidogenic and steroid-inactivating enzymes and adrenal and sex steroid receptors. Molecular and Cellular Endocrinology 215 55-62. (doi:10.1016/j.mce.2003.11.007)

Beggah AT, Escoubet B, Puttini S, Cailmail S, Delage V, Ouvrard-Pascaud A, Bocchi B, Peuchmaur M, Delcayre C, Farman N, et al. 2002 Reversible cardiac fibrosis and heart failure induced by conditional expression of an antisense mRNA of the mineralocorticoid receptor in cardiomyocytes. PNAS 99 7160-7165. (doi:10.1073/ pnas.102673599)

Berger S, Bleich M, Schmid W, Cole TJ, Peters J, Watanabe H, Kriz W, Warth R, Greger R \& Schutz G 1998 Mineralocorticoid receptor
๑ 2017 Society for Endocrinology Printed in Great Britain 
knockout mice: pathophysiology of $\mathrm{Na}+$ metabolism. PNAS 95 9424-9429. (doi:10.1073/pnas.95.16.9424)

Berger S, Wolfer DP, Selbach O, Alter H, Erdmann G, Reichardt HM, Chepkova AN, Welzl H, Haas HL, Lipp HP, et al. 2006 Loss of the limbic mineralocorticoid receptor impairs behavioral plasticity. PNAS 103 195-200. (doi:10.1073/pnas.0503878102)

Bienvenu LA, Morgan J, Rickard AJ, Tesch GH, Cranston GA, Fletcher EK, Delbridge LM \& Young MJ 2012 Macrophage mineralocorticoid receptor signaling plays a key role in aldosterone-independent cardiac fibrosis. Endocrinology 153 3416-3425. (doi:10.1210/ en.2011-2098)

Bienvenu LA, Reichelt ME, Morgan J, Fletcher EK, Bell JR, Rickard AJ, Delbridge LM \& Young MJ 2015 Cardiomyocyte mineralocorticoid receptor activation impairs acute cardiac functional recovery after ischemic insult. Hypertension 66 970-977. (doi:10.1161/ HYPERTENSIONAHA.115.05981)

Bleich M, Warth R, Schmidt-Hieber M, Schulz-Baldes A, Hasselblatt P, Fisch D, Berger S, Kunzelmann K, Kriz W, Schutz G, et al. 1999 Rescue of the mineralocorticoid receptor knock-out mouse. Pflügers Archiv 438 245-254. (doi:10.1007/s004240050906)

Boix J, Sevilla LM, Saez Z, Carceller E \& Perez P 2016 Epidermal mineralocorticoid receptor plays beneficial and adverse effects in skin and mediates glucocorticoid responses. Journal of Investigative Dermatology 136 2417-2426. (doi:10.1016/j.jid.2016.07.018)

Brinks V, Berger S, Gass P, de Kloet ER \& Oitzl MS 2009 Mineralocorticoid receptors in control of emotional arousal and fear memory. Hormones and Behavior 56 232-238. (doi:10.1016/j.yhbeh.2009.05.003)

Canonica J, Sergi C, Maillard M, Klusonova P, Odermatt A, Koesters R, Loffing-Cueni D, Loffing J, Rossier B, Frateschi S, et al. 2016 Adult nephron-specific MR-deficient mice develop a severe renal PHA-1 phenotype. Pflügers Archiv 468 895-908. (doi:10.1007/s00424-0151785-2)

Cole TJ, Blendy JA, Monaghan AP, Krieglstein K, Schmid W, Aguzzi A, Fantuzzi G, Hummler E, Unsicker K \& Schutz G 1995 Targeted disruption of the glucocorticoid receptor gene blocks adrenergic chromaffin cell development and severely retards lung maturation. Genes and Development 9 1608-1621. (doi:10.1101/gad.9.13.1608)

Cole TJ, Terella L, Morgan J, Alexiadis M, Yao YZ, Enriori P, Young MJ \& Fuller PJ 2015 Aldosterone-mediated renal sodium transport requires intact mineralocorticoid receptor DNA-binding in the mouse. Endocrinology 156 2958-2968. (doi:10.1210/en.2015-1008)

de Kloet ER, Joels M \& Holsboer F 2005 Stress and the brain: from adaptation to disease. Nature Reviews Neuroscience 6 463-475. (doi:10.1038/nrn1683)

el Marjou F, Janssen KP, Chang BH, Li M, Hindie V, Chan L, Louvard D, Chambon P, Metzger D \& Robine S 2004 Tissue-specific and inducible Cre-mediated recombination in the gut epithelium. Genesis 39 186-193. (doi:10.1002/gene.20042)

Fraccarollo D, Berger S, Galuppo P, Kneitz S, Hein L, Schutz G, Frantz S, Ertl G \& Bauersachs J 2011 Deletion of cardiomyocyte mineralocorticoid receptor ameliorates adverse remodeling after myocardial infarction. Circulation 123 400-408. (doi:10.1161/ CIRCULATIONAHA.110.983023)

Friedel RH, Wurst W, Wefers B \& Kuhn R 2011 Generating conditional knockout mice. Methods in Molecular Biology 693 205-231. (doi:10.1007/978-1-60761-974-1_12)

Frieler RA, Meng H, Duan SZ, Berger S, Schutz G, He Y, Xi G, Wang MM \& Mortensen RM 2011 Myeloid-specific deletion of the mineralocorticoid receptor reduces infarct volume and alters inflammation during cerebral ischemia. Stroke 42 179-185. (doi:10.1161/STROKEAHA.110.598441)

Frieler RA, Ray JJ, Meng H, Ramnarayanan SP, Usher MG, Su EJ, Berger S, Pinsky DJ, Lawrence DA, Wang MM, et al. 2012 Myeloid mineralocorticoid receptor during experimental ischemic stroke: effects of model and sex. Journal of the American Heart Association $\mathbf{1}$ e002584. (doi:10.1161/jaha.112.002584)
Funder JW 2010 Minireview: aldosterone and mineralocorticoid receptors: past, present, and future. Endocrinology 151 5098-5102. (doi:10.1210/en.2010-0465)

Funder JW 2017 Apparent mineralocorticoid excess. Journal of Steroid Biochemistry and Molecular Biology 165 151-153. (doi:10.1016/j. jsbmb.2016.03.010)

Gass P, Kretz O, Wolfer DP, Berger S, Tronche F, Reichardt HM, Kellendonk C, Lipp HP, Schmid W \& Schutz G 2000 Genetic disruption of mineralocorticoid receptor leads to impaired neurogenesis and granule cell degeneration in the hippocampus of adult mice. $E M B O$ Reports 1 447-451. (doi:10.1093/embo-reports/kvd088)

Geller DS, Farhi A, Pinkerton N, Fradley M, Moritz M, Spitzer A, Meinke G, Tsai FT, Sigler PB \& Lifton RP 2000 Activating mineralocorticoid receptor mutation in hypertension exacerbated by pregnancy. Science 289 119-123. (doi:10.1126/science.289.5476.119)

Gomez-Sanchez E \& Gomez-Sanchez CE 2014 The multifaceted mineralocorticoid receptor. Comprehensive Physiology 4 965-994. (doi:10.1002/cphy.c130044)

Hoppmann J, Perwitz N, Meier B, Fasshauer M, Hadaschik D, Lehnert H \& Klein J 2010 The balance between gluco- and mineralo-corticoid action critically determines inflammatory adipocyte responses. Journal of Endocrinology 204 153-164. (doi:10.1677/JOE-09-0292)

Hubert C, Gasc JM, Berger S, Schutz G \& Corvol P 1999 Effects of mineralocorticoid receptor gene disruption on the components of the renin-angiotensin system in 8-day-old mice. Molecular Endocrinology 13 297-306. (doi:10.1210/mend.13.2.0241)

Jia G, Habibi J, DeMarco VG, Martinez-Lemus LA, Ma L, WhaleyConnell AT, Aroor AR, Domeier TL, Zhu Y, Meininger GA, et al. 2015 Endothelial mineralocorticoid receptor deletion prevents diet-induced cardiac diastolic dysfunction in females. Hypertension 66 1159-1167. (doi:10.1161/HYPERTENSIONAHA.115.06015)

Jia G, Habibi J, Aroor AR, Martinez-Lemus LA, DeMarco VG, RamirezPerez FI, Sun Z, Hayden MR, Meininger GA, Mueller KB, et al. 2016 Endothelial mineralocorticoid receptor mediates diet-induced aortic stiffness in females. Circulation Research 118 935-943. (doi:10.1161/ CIRCRESAHA.115.308269)

Karst H, Berger S, Turiault M, Tronche F, Schutz G \& Joels M 2005 Mineralocorticoid receptors are indispensable for nongenomic modulation of hippocampal glutamate transmission by corticosterone. PNAS 102 19204-19207. (doi:10.1073/pnas.0507572102)

Kolber BJ, Wieczorek L \& Muglia LJ 2008 Hypothalamic-pituitary-adrenal axis dysregulation and behavioral analysis of mouse mutants with altered glucocorticoid or mineralocorticoid receptor function. Stress 11 321-338. (doi:10.1080/10253890701821081)

Lai M, Horsburgh K, Bae SE, Carter RN, Stenvers DJ, Fowler JH, Yau JL, Gomez-Sanchez CE, Holmes MC, Kenyon CJ, et al. 2007 Forebrain mineralocorticoid receptor overexpression enhances memory, reduces anxiety and attenuates neuronal loss in cerebral ischaemia. European Journal of Neuroscience 25 1832-1842. (doi:10.1111/j.14609568.2007.05427.x)

Lim HY, van den Brandt J, Fassnacht M, Allolio B, Herold MJ \& Reichardt HM 2008 Silencing of the mineralocorticoid receptor by ribonucleic acid interference in transgenic rats disrupts endocrine homeostasis. Molecular Endocrinology 22 1304-1311. (doi:10.1210/me.2007-0417)

Lother A, Berger S, Gilsbach R, Rosner S, Ecke A, Barreto F, Bauersachs J, Schutz G \& Hein L 2011 Ablation of mineralocorticoid receptors in myocytes but not in fibroblasts preserves cardiac function. Hypertension 57 746-754. (doi:10.1161/ HYPERTENSIONAHA.110.163287)

Martinerie L, Viengchareun S, Delezoide AL, Jaubert F, Sinico M, Prevot S, Boileau P, Meduri G \& Lombes M 2009 Low renal mineralocorticoid receptor expression at birth contributes to partial aldosterone resistance in neonates. Endocrinology 150 4414-4424. (doi:10.1210/ en.2008-1498)

Martinerie L, Viengchareun S, Meduri G, Kim HS, Luther JM \& Lombes M 2011 Aldosterone postnatally, but not at birth, is required for optimal

Published by Bioscientifica Ltd. 
induction of renal mineralocorticoid receptor expression and sodium reabsorption. Endocrinology 152 2483-2491. (doi:10.1210/en.2010-1460)

McCurley A, Pires PW, Bender SB, Aronovitz M, Zhao MJ, Metzger D, Chambon P, Hill MA, Dorrance AM, Mendelsohn ME, et al. 2012 Direct regulation of blood pressure by smooth muscle cell mineralocorticoid receptors. Nature Medicine 18 1429-1433. (doi:10.1038/nm.2891)

McKenna NJ, Evans RM \& O’Malley BW 2014 Nuclear receptor signaling: a home for nuclear receptor and coregulator signaling research. Nuclear Receptor Signaling 12 e006.

Montes-Cobos E, Li X, Fischer HJ, Sasse A, Kugler S, Didie M, Toischer K, Fassnacht M, Dressel R \& Reichardt HM 2015 Inducible knock-down of the mineralocorticoid receptor in mice disturbs regulation of the renin-angiotensin-aldosterone system and attenuates heart failure induced by pressure overload. PLOS ONE 10 e0143954. (doi:10.1371/ journal.pone.0143954)

Mueller KB, Bender SB, Hong K, Yang Y, Aronovitz M, Jaisser F, Hill MA \& Jaffe IZ 2015 Endothelial mineralocorticoid receptors differentially contribute to coronary and mesenteric vascular function without modulating blood pressure. Hypertension 66 988-997. (doi:10.1161/ HYPERTENSIONAHA.115.06172)

Obradovic D, Tirard M, Nemethy Z, Hirsch O, Gronemeyer H \& Almeida OF 2004 DAXX, FLASH, and FAF-1 modulate mineralocorticoid and glucocorticoid receptor-mediated transcription in hippocampal cells toward a basis for the opposite actions elicited by two nuclear receptors? Molecular Pharmacology 65 761-769. (doi:10.1124/mol.65.3.761)

Pitt B, Zannad F, Remme WJ, Cody R, Castaigne A, Perez A, Palensky J \& Wittes J 1999 The effect of spironolactone on morbidity and mortality in patients with severe heart failure. Randomized Aldactone Evaluation Study Investigators. New England Journal of Medicine 341 709-717. (doi:10.1056/NEJM199909023411001)

Pitt B, Williams G, Remme W, Martinez F, Lopez-Sendon J, Zannad F, Neaton J, Roniker B, Hurley S, Burns D, et al. 2001 The EPHESUS trial: eplerenone in patients with heart failure due to systolic dysfunction complicating acute myocardial infarction. Eplerenone post-AMI heart failure efficacy and survival study. Cardiovascular Drugs and Therapy 15 79-87. (doi:10.1023/A:1011119003788)

Pruthi D, McCurley A, Aronovitz M, Galayda C, Karumanchi SA \& Jaffe IZ 2014 Aldosterone promotes vascular remodeling by direct effects on smooth muscle cell mineralocorticoid receptors. Arteriosclerosis, Thrombosis, and Vascular Biology 34 355-364. (doi:10.1161/ ATVBAHA.113.302854)

Rafestin-Oblin ME, Souque A, Bocchi B, Pinon G, Fagart J \& Vandewalle A 2003 The severe form of hypertension caused by the activating S810L mutation in the mineralocorticoid receptor is cortisone related. Endocrinology 144 528-533. (doi:10.1210/en.2002-220708)

Ran FA, Hsu PD, Wright J, Agarwala V, Scott DA \& Zhang F 2013 Genome engineering using the CRISPR-Cas9 system. Nature Protocols $\mathbf{8}$ 2281-2308. (doi:10.1038/nprot.2013.143)

Reichardt HM, Kaestner KH, Tuckermann J, Kretz O, Wessely O, Bock R, Gass P, Schmid W, Herrlich P, Angel P, et al. 1998 DNA binding of the glucocorticoid receptor is not essential for survival. Cell 93 531-541. (doi:10.1016/S0092-8674(00)81183-6)

Rickard AJ, Morgan J, Tesch G, Funder JW, Fuller PJ \& Young MJ 2009 Deletion of mineralocorticoid receptors from macrophages protects against deoxycorticosterone/salt-induced cardiac fibrosis and increased blood pressure. Hypertension 54 537-543. (doi:10.1161/ HYPERTENSIONAHA.109.131110)

Rickard AJ, Morgan J, Bienvenu LA, Fletcher EK, Cranston GA, Shen JZ, Reichelt ME, Delbridge LM \& Young MJ 2012 Cardiomyocyte mineralocorticoid receptors are essential for deoxycorticosterone/ salt-mediated inflammation and cardiac fibrosis. Hypertension 60 1443-1450. (doi:10.1161/HYPERTENSIONAHA.112.203158)

Rickard AJ, Morgan J, Chrissobolis S, Miller AA, Sobey CG \& Young MJ 2014 Endothelial cell mineralocorticoid receptors regulate deoxycorticosterone/salt-mediated cardiac remodeling and vascular reactivity but not blood pressure. Hypertension 63 1033-1040. (doi:10.1161/HYPERTENSIONAHA.113.01803)

Rogerson FM, Yao YZ, Young MJ \& Fuller PJ 2014 Identification and characterization of a ligand-selective mineralocorticoid receptor coactivator. FASEB Journal 28 4200-4210. (doi:10.1096/fj.13-242479)

Ronzaud C, Loffing J, Bleich M, Gretz N, Grone HJ, Schutz G \& Berger S 2007 Impairment of sodium balance in mice deficient in renal principal cell mineralocorticoid receptor. Journal of the American Society of Nephrology 18 1679-1687. (doi:10.1681/ASN.2006090975)

Rozeboom AM, Akil H \& Seasholtz AF 2007 Mineralocorticoid receptor overexpression in forebrain decreases anxiety-like behavior and alters the stress response in mice. PNAS 104 4688-4693. (doi:10.1073/ pnas.0606067104)

Schafer N, Lohmann C, Winnik S, van Tits LJ, Miranda MX, Vergopoulos A, Ruschitzka F, Nussberger J, Berger S, Luscher TF, et al. 2013 Endothelial mineralocorticoid receptor activation mediates endothelial dysfunction in diet-induced obesity. European Heart Journal 34 3515-3524. (doi:10.1093/eurheartj/eht095)

Shen JZ, Morgan J, Tesch GH, Rickard AJ, Chrissobolis S, Drummond GR, Fuller PJ \& Young MJ 2016 Cardiac tissue injury and remodeling is dependent upon MR regulation of activation pathways in cardiac tissue macrophages. Endocrinology 157 3213-3223. (doi:10.1210/en.2016-1040)

Sun Z, Bello-Roufai M \& Wang X 2008 RNAi inhibition of mineralocorticoid receptors prevents the development of cold-induced hypertension. American Journal of Physiology: Heart and Circulatory Physiology 294 H1880-H1887. (doi:10.1152/ajpcell.00129.2008)

Sun JY, Li C, Shen ZX, Zhang WC, Ai TJ, Du LJ, Zhang YY, Yao GF, Liu Y, Sun S, et al. 2016 Mineralocorticoid receptor deficiency in macrophages inhibits neointimal hyperplasia and suppresses macrophage inflammation through SGK1-AP1/NF-kappaB pathways. Arteriosclerosis, Thrombosis, and Vascular Biology 36 874-885. (doi:10.1161/ATVBAHA.115.307031)

Terker AS, Yarbrough B, Ferdaus MZ, Lazelle RA, Erspamer KJ, Meermeier NP, Park HJ, McCormick JA, Yang CL \& Ellison DH 2016 Direct and indirect mineralocorticoid effects determine distal salt transport. Journal of the American Society of Nephrology 27 2436-2445. (doi:10.1681/ASN.2015070815)

Usher MG, Duan SZ, Ivaschenko CY, Frieler RA, Berger S, Schutz G, Lumeng CN \& Mortensen RM 2010 Myeloid mineralocorticoid receptor controls macrophage polarization and cardiovascular hypertrophy and remodeling in mice. Journal of Clinical Investigation 120 3350-3364. (doi:10.1172/JCI41080)

Wintermantel TM, Berger S, Greiner EF \& Schutz G 2005 Evaluation of steroid receptor function by gene targeting in mice. Journal of Steroid Biochemistry and Molecular Biology 93 107-112. (doi:10.1016/j. jsbmb.2004.12.033)

Yang J \& Young MJ 2016 Mineralocorticoid receptor antagonistspharmacodynamics and pharmacokinetic differences. Current Opinion in Pharmacology 27 78-85. (doi:10.1016/j.coph.2016.02.005)

Young MJ \& Funder JW 1996 The renin-angiotensin-aldosterone system in experimental mineralocorticoid-salt-induced cardiac fibrosis. American Journal of Physiology 271 E883-E888.

Zannad F, McMurray JJ, Krum H, van Veldhuisen DJ, Swedberg K, Shi H, Vincent J, Pocock SJ, Pitt B \& Group E-HS 2011 Eplerenone in patients with systolic heart failure and mild symptoms. New England Journal of Medicine 364 11-21. (doi:10.1056/NEJMoa1009492)

Received in final form 24 May 2017

Accepted 26 May 2017

Accepted Preprint published online 26 May 2017 http://joe.endocrinology-journals.org

DOI: $10.1530 / J O E-17-0155$
(C) 2017 Society for Endocrinology Printed in Great Britain
Published by Bioscientifica Ltd. 